\title{
CSR as a Driver of Corporate Reputation: Family Firms in the Italian Luxury Industry
}

\author{
Patrizia Gazzola ${ }^{1}$, Stefano Amelio ${ }^{2} \&$ Roberta Pezzetti ${ }^{1}$ \\ ${ }^{1}$ Department of Economics, University of Insubria, Varese, Italy \\ ${ }^{2}$ Department of Business Economics and Law (Di.SEA.DE), University of Milano-Bicocca, Milano, Italy \\ Correspondence: Stefano Amelio, Department of Business Economics and Law (Di.SEA.DE), University of Milano- \\ Bicocca, Milano, Italy.
}

Received: September 1, 2020

Accepted: October 1, 2020

Online Published: October 19, 2020

doi:10.5430/ijba.v11n6p21

URL: https://doi.org/10.5430/ijba.v11n6p21

The research is financed by Sponsoring information.

\begin{abstract}
The aim of the paper is to analyse the relationship between Corporate Social Responsibility (CSR) and brand reputation in the luxury sector. In particular, the paper from one hand analyzes the drivers that lead to a growing integration of social responsibility in the competitive strategies of luxury firms and, on the other hand focuses on the role of CSR as a driver of brand reputation. Starting from review of the literature, the factors that influence the reputation in the brand-based global luxury industry are discussed, highlighting a gradual shift from reputation based on product quality to one focused on firm's sustainability. The methodology also includes three case studies of Italian family firms representing best practices in CRS reputation according to 2015 version of Standard Ethics Italian Index: Brunello Cucinelli, Damiani and Luxottica. The study highlights the increasing role CSR practices are assuming in the luxury industry along with the needs for luxury firms to adopt strategic innovations and innovative business models coherent with the principles of sustainability. Furthermore, the analysis illustrates how different socially responsible behaviors have influenced the economic results of the three companies analyzed. The empirical evidences contribute to the CSR and reputation literature by focusing on Italian family firms operating in the luxury sector.
\end{abstract}

Keywords: family firms, responsible luxury, corporate social responsibility, reputation, new business paradigms, ethical standards

\section{Introduction}

The luxury industry is going to CSR. This transition is continuous, albeit slow. As a consequence of the anti-fur campaigns (in the 80s and 90s), numerous luxury brands and retailers started to act in this direction, adopting methods for guarantee animal welfare both in production and distribution processes. In recent years, the luxury industry has entered in a new phase characterized by a business approach based on "responsible luxury", in parallel to growing incisive criticisms related to its environmental footprint. Luxury companies are today showing a growing responsible approach towards both the environment and the society, following a variety of economic, environmental and social drives (Dekhili, Achabou, \& Alharbi, 2019; Colombo \& Gazzola, 2015a; Pavione \& Pezzetti, 2015). Not only companies but also wealthy consumers show a growing attention towards sustainable forms of luxury, a luxury that in respecting the environment and society does not forget quality and originality (Pencarelli et al., 2020; Pavione, Pezzetti \& Dall'Ava, 2016). As a consequence of this double awareness, the luxury industry has had to modify business strategies by incorporating environmental and social issues in addition to economic ones; companies have therefore incorporated social responsibility into their strategic approach and in the value chains (Jaegler \& Goessling, 2020).

In this context, luxury brands are today more and more aware of the importance to demonstrate that both their image and corporate identity are based on a set of values that can be recognized and judged publicly by customers and the market; according to this focus, strategies of CSR represent a response for improving the value of luxury brands and for strengthening the relationship with customers. 
Several factors are driving luxury companies to responsible behavior (Mella \& Gazzola, 2018), in a business framework which shows a growing attention to corporate social responsibility practices and strategies (FernándezGago, Cabeza-García, \& Nieto, 2016; Graf \& Wirl, 2014; Reverte, 2016; Bussoli \& Conte, 2018). For companies, it is becoming increasingly important to demonstrate their sustainability efforts as consumers care more about environmental and social issues (Gazzola, Amelio, Fragkoulis \& Zenon, 2019; Gazzola, Pezzetti, Amelio \& Grechi, 2020). As sustainability and CSR have become a critical focus in driving consumer's demand, in all sectors a growing number of companies are implementing CSR strategies to improve their brand reputation in order to appear more attractive both to customers and potential investors (Bianchi, Bruno \& Sarabia-Sanchez, 2019; Othman, Darus, $\&$ Arshad, 2011). Some sectors have been faster in implementing sustainable strategies. (i.e. oil and gas) while others have been slower. The fashion and luxury goods sectors fall into the second category. Little has been said about the relationship between CSR and reputation in the luxury industry although many researchers have stated that it is positive. Furthermore, corporate reputation can be considered the mediator in the connection between the company's CSR and the company's economic-financial result (Vitezic, 2011; Sabri \& Sweis, 2016; Brammer \& Pavelin, 2006; Fombrun, 2005; Andriof \& Waddock, 2002).

The aim of the paper is to clarify the significant association connecting CSR and reputation in the luxury sector. In particular, the paper focuses on family firms. Nowadays, family businesses represent a very important economic reality in more developed western countries, where they often play a vital role not only in economic life but also in the social one (Alonso-Dos-Santos \& Llanos-Contreras, 2019; Basco \& Calabrò, 2017; Gnan \& Montemerlo, 2002; Santos, 2011). It is not easy to identify the concept of family firms also because, as stated by Zody Sprenkle, MacDermid and Schrank (2006), it is difficult to identify the boundary between family and family firm. Traditionally, in literature there are various and not always coinciding definitions (Table 1).

Family firms are particularly attentive to issues related to social responsibility (Zeng, 2020), as they give rise to socially responsible activities (Berrone, Cruz, \& Gomez-Mejia, 2012) in order to strength a positive responsible relationships with their stakeholders (Singh \& Mittal, 2019; Dyer \& Whetten, 2006). According to the literature, family firms are mainly active in practices concerning employees (Silva Vilela, de Oliveira Santos Jhunior \& Lemos Lourenço, 2020; Marques, Presas, \& Simon, 2014), customers (Zanon et al., 2019; Kashmiri \& Mahajan, 2014) and the social community in which they are rooted (Pini, 2019; Block \& Wagner, 2014; Cruz, Larraza-Kintana, GarcésGaldeano, \& Berrone, 2014).

According to the study conducted by Dyer and Whetten (2006), family firms have a stronger sense of responsibility towards society with the purpose of safeguarding their image and their reputation and for this reason very often they donate time and money for supporting projects, associations and events without having any economic returns. According to Aronoff and Ward (1991), it is appropriate to extend the benefits of the family dimension to other stakeholders outside the company such as customers and suppliers who operate and therefore to be part of the same value chain; the reputation of family businesses and their relationships with these categories of stakeholders would seem to be more solid and aimed at creating value than non-family businesses.

In light of this, the main contribution of the paper is to investigate the existence of a connection between reputation and CSR. In detail, the study provides an analysis of the main factors pushing luxury family businesses to incorporate social responsibility into their competitive strategies to, consequently, enhance the brand reputation. The paper is divided into two sections: in the first part, after conducting a literature review, the factors that affect the reputation in the brand-based global luxury industry are examined. In the second one, three case studies of Italian family firms which represent best practices in CRS reputation are analysed. The paper is based on 3 research questions: Are companies acting in the luxury industry responsible? Can CSR improve reputation? What effects does CSR have on reputation in Luxury industry? The analysis conducted on 3 Italian companies allows understanding how different socially responsible behaviors have influenced their economic results, thus highlighting the relationship between CSR and performance.

Table 1. Family firms: definitions

"Closely identified with at least two generations of a family; link has had a mutual influence on company policy and the interests and objectives of the

Donnelley (1964) family"

Miller and Rice (1973)

"Members of one family own enough voting equity to control strategic policy and tactical implementation" 


\begin{tabular}{ll}
\hline Barry (1975) & "Ownership control by the members of a single family" \\
\hline Barnes and Hershon (1976) & "Ownership control by a single family or individual" \\
\hline Becker and Tillman (1978) & "A small or closely-held business" \\
\hline Davis (1983) & $\begin{array}{l}\text { "Interaction between family and business organizations that determines the } \\
\text { nature and uniqueness of the business" }\end{array}$ \\
\hline Dyer (1986) & "Family influence over business decisions" \\
\hline Ward (1987) & "Transfer of ownership across at least two generations" \\
\hline Hollander and Helman (1988) & "Continuous relationship between family and business" \\
\hline
\end{tabular}

\section{CSR as a Driver of Corporate Reputation: Literature Review}

\subsection{The Relation Between Strategy and CSR}

As evidenced by Aggarwal and Singh (2019) and by Gazzola and Colombo (2014), citing the thought of Freeman and Hasnaoui (2010), CSR is still understood differently and therefore there is no global uniformity of the concept. Companies which decides to introduce corporate social responsibility practices into the management systems should both demonstrate that they are able both to incorporate CSR into business strategy (Siltaloppi, Rajala \& Hietala, 2020; Mirvis \& Googins, 2006) and, at the same time, to effectively revise operational practices. Porter and Kramer $(2002,2006)$ and Galbreath (2009) propose an analytical model based on the role of CSR in the competitive context and the responsible impacts of the value chain (de Leaniz \& Ruiz, 2019). As mentioned by Vitolla and Rubino (2013), for the integration of CSR into corporate strategy Sharp and Zaidman (2010) enforce Jarzabkowski's triangular model (2005) which highlights the existing connection among three elements (strategy, organization community and management) (Gazzola \& Colombo, 2014). McKinsey (2009), underlines how the top management is in agreement on considering CSR as a strategic business element (Kiesnere \& Baumgartner, 2019). Szöcs and Schlegelmilch (2020), Siltaloppi, Rajala and Hietala (2020), Berland and Essid (2009), Norris and O'Dwyer (2004) and Adams (2002) conduct other researches on the connection between CSR and strategy. Colombo and Gazzola (2015b) present a model that integrates CSR within both strategy and management systems.

\subsection{Corporate Reputation and CSR}

Stakeholders, in particular consumers (Lee \& Marshall, 2013) and workers (Kucharska, 2020; Mella \& Gazzola, 2015, Gazzola, 2018), consider reputation as a central element for evaluating companies (Tetrault Sirsly \& Lvina, 2019; Gray \& Ballmer, 2006; Rhee \& Haunschild, 2006). According to Fombrun (1996) "corporate reputation is a perceptual representation of a company's past actions and future prospects that describe the firm's overall appeal to all of its key constituents when compared with other leading rivals". It could also be considered as precursor of corporate social responsibility (Schnietz \& Epstein, 2005).

The reputation construct is "a collective representation of a firm's past actions and results that describe the firm's ability to deliver multiple stakeholders" (Fombrun \& van Riel, 1997 p.10). According to Deephouse (2000), reputation is an exclusive element, difficult to copy and replicate. In accordance with Roberts (2003), companies "maintain good reputation if they continue to meet the expectations of their key stakeholders, which for most companies includes a high level of corporate social responsibility". Martín-de-Castro, Navas, and Sáez (2006) separate the reputation theory into: reputation of customers and employees (business reputation) and social reputation (the community).

According to Fombrun (1996), the notion of corporation reputation "is based on the set of values and principles employees and managers associate with the company". Beheshtifar and Korouki (2013) affirm that organizations that manage their corporate reputation very well have highlighted these elements:

- distinctiveness: firms occupied a distinct place in the views of stakeholders;

- focus: firms emphasized a core strategy;

- consistency: firms were consistent in their communications with all stakeholders;

- identity: firms were seen as genuine by stakeholders;

- transparency: firms were seen as open and forthright in going about their business".

Zyglidoupoulos (2001) defines reputation "as the set of knowledge and emotions held by various stakeholder groups 
concerning aspect of a firm and its activities". Several authors dwell on this concept and deepen it under various aspects (Kelley, Hemphill \& Thams, 2019; Park, 2019; Barnett, Johnston, \& Hillard, 2006; Bartel, Blader, \& Wrzesniewski, 2007; Bouchikhi \& Kimberly, 2008; Gazzola, 2014b).

Several scholars (Sciarelli, Tani, Landi and Turriziani, 2020, Claver-Cortés et al., 2019, Fombrun, 1996) agree on the existence of a close relationship between a person's perception of a company and business success. A global research conducted by McKinsey in 2010 shows that the majority of top management believes that CSR positively affects the long-term shareholder value as well as the corporate reputation. On the contrary, the absence of CSR determines the loss of value of the company's shares (and the consequent sale of the same) with a subsequent reduction in company results (Chatterji, Levine and Toffel, 2009). As highlighted by Gazzola (2018) studies about the correlation between CSR and reputation in the luxury sector are still today a neglected research area in the managerial literature.

The paper provides an empirical evidence on the existing positive relationship between CSR and reputation in the luxury sector by presenting three virtuous examples of Italian family firms, which have been analyzed by focusing on their internet disclosure. As Sageder, Mitter and Feldbauer-Durstmüller (2018) state, "Since the mid-1990s, reputation and image of family firms have been the subject of conceptual and empirical studies in various journals, highlighting the growing interest in this topic. However, depending on the research focus, only individual aspects of image and reputation have been investigated, or they have been considered sub-aspects of other research lines". Although the managerial literature shows studies relating to the relationship between family firms and reputation (Sageder, Mitter and Feldbauer-Durstmüller, 2018; Astrachan, Botero, Astrachan \& Prügl, 2018) and studies about family firms in the luxury sector (Carcano, Corvetta, \& Minichilli, 2011), a specific study analysing the linkages among these topics (CSR, reputation, family firms and luxury sector) has never been conducted, notwithstanding the luxury industry is a leading industry in the Italian economy and despite, as Gavana, Gottardo and Moisello (2018) state, CSR is more effective for family firms.

\section{CSR and "Responsible Luxury": Towards CSR Reputation}

According to Pavione, Pezzetti and Dall'Ava (2016), the consideration of "social responsibility requires a company to constantly examine the impact of its own actions on all stakeholders, coordinating the interests of the latter with its own". Although conventional literature talks about economic and social objectives contrasting each other (Friedman, 2007), in recent decades, literature has started to speak of coexistence. It also stressed how social goals could develop into basic elements of competitive advantage (Porter \& Kramer, 2002).

Gazzola, Pezzetti and Pavione (2019) show how CSR in the luxury and fashion industry has developed only in recent years. Initially, the social responsibility of luxury and fashion companies focused only on communication strategies (ecological marketing). Subsequently (starting from mid '90s) luxury companies moved towards new production and organizational paradigms based on the pursuit of social strategies attentive to the environment and society. Social responsibility, in addition to innovation and internationalization, includes several factors such as "respect and protection of the environment, promotion of human resources, safety and protection of health and working conditions, thus becoming a fundamental driver for competitiveness and for supporting firm's development" (Pavione, Pezzetti, \& Dall'Ava, 2016).

Corporate social responsibility is linked to the concept of sustainability, from the threefold economic, social and environmental point of view. Social responsibility and sustainability are related elements (Rendtorff, 2019). Over time, the concept of sustainability has replaced that of social responsibility (Giron, 2010).

CSR and sustainability influence the entire value chain, from upstream to downstream, i.e. from the extraction of raw materials to the relationships with final consumers, in a network that is ever more complex (Mollet, von Arx, \& Ilić, 2013). Companies with the best performances from the sustainability point of view are able to insert sustainability into the governance processes, thus seizing the development opportunities deriving from a sustainable approach (Hoffmann \& Coste-Maniere, 2012). Besides, CRS offers to luxury firms the opportunity to replace outdated "compete and consume" business models with new ones, based on collaboration within an enlarged network of (secondary) stakeholders (Donato, Amatulli \& De Angelis, 2019). Such models are able to build resilience across the overall luxury supply chain through enhanced efficiency and the implementation of innovative approaches for raw material production and exploitation, as previously noted.

As widely discussed in the literature, a close relationship exists between innovation and business sustainable approaches. Sustainability brings innovation from multiple perspectives (commercial, organizational, social and technological) and, especially from the environmental view point, has a strong impact on luxury business models, 
influencing information on branding policies (Advantage, 2020), on the product dimension and on supply relationships (Allen, Walker, \& Brady, 2012; Guercini \& Ranfagni, 2012). Hence the fashion-luxury market becomes a "privileged laboratory for observing and analyzing the socially responsible behavior of companies" (Pavione, Pezzetti, \& Dall'Ava, 2016).

The luxury industry and the fashion market in particular, is a brand-based industry dominated by global brands. The administration of the high quality fashion brands, therefore, represents an essential element of the marketing strategy for luxury goods. It is a complex task which requires a consistent and coherent approach, frequently counter-intuitive (Tynan, McKechnie, \& Chhuon, 2010). Although brand reputation represents a topic highly investigated in the management and marketing literature (Bartikowski, Fastoso \& Gierl, 2020), there are still few contributions (both theoretical and empirical) about the effects of CSR and sustainability on reputation of luxury brands. This lack in the analysis reflects the evidence that in the luxury industry the integration of CRS and sustainability into the firm's core values and strategy is becoming a critical factor only in very recent years and yet today only a small number of luxury companies consider sustainability as a strategic value creator means, both for customers and other stakeholders. Sustainability strategies and practices, in particular when they involve interactive collaboration with different stakeholders, can help luxury firms to co-create a superior value proposition for their brands, with positive effects not only on consumers' buying behaviour, but also on brand image and brand reputation. Reputation, in particular, appears to be of great importance in today global competitive framework where luxury companies are more and more asked to satisfy numerous stakeholders' expectancies (and multiple sub-segments of demand) within different cultural contexts; in this framework, luxury firms compete for reputational status. Traditionally, in the luxury fashion industry brand reputation has been created and maintained putting emphasize on the outstanding quality of products. Only in very recent time, sustainability is gradually becoming a new source of value for luxury fashion brands, which integrate traditional value dimensions like excellence in quality (Holbrook, 1999), craftsmanship (Kapferer, 1997), social identity (Vikers \& Renard, 2003), rarity (Catry, 2003) and authenticity (Beverland, 2006). On one hand, luxury brands have a need for sustainability as they are by definition dependent on natural resources. On the other hands, brand reputation based on sustainability seems start exercising a growing influence on both consumers' buying decisions and investors intentions, in particular in developed mature markets. These considerations lead today luxury brands to pay increasing attention to the incorporation of CSR (and consequently sustainability) in the corporate strategy and in brand management practices. For luxury global brands, building up sustainable reputation represents today a challenging goal: global players (which often possess extensive luxury brand portfolio) need to build local CSR reputation, engaging a network of relationships with local community actors, while simultaneously demonstrating a proactive approach to global social responsibility. The proactive management, both at local and international level, of a network of collaborative relationships with different stakeholders for achieving social performance offers not only new opportunities for engaging high-end customers and strategic third parties into new forms of value co-creation, but also it represents a key tool for an effective brand differentiation based on reputation. In an industry where emotional bonds between the firm and customers play a fundamental role in driving consumers' choices, CSR reputation is becoming an important driver of both luxury global brand perception and brand evaluation. Customer loyalty connected to sustainability reputation could act in the future as an implicit "brand reputation insurance", which can represents an element of particular strategic importance for luxury global brands committed to tackling rapid changes both in consumers' demand and competitive landscape.

CRS reputation requires credibility of firm's engagement in CSR and sustainability practices. In accordance with François-Henri Pinault, Chairman and CEO of the French Kering Group, in the next years luxury fashion brands will have to incorporate sustainability into commercial strategies, as it becomes a source of differentiation, efficiency and competitiveness, along with an innovation tool capable of attracting talent (Janssen, Vanhamme, Lindgreen \& Lefebvre, 2014). In the Kering Group, sustainability is integrated into the corporate mission: each Group brand operates in this direction of environmental sustainability. Examples of initiatives, among others, are the Green Carpet Challenge collection launched in September 2014 by Stella McCartney' brand during the London Fashion Week, which laid the foundations for sustainable fashion based on environmental protection and ethical principles; the innovative and sustainable fashion sunglasses collection by Gucci made in liquid wood; innovative and exclusive bio-synthetic products by Stella McCartney conceived to replace leather in bags, shoes and eyewear products. Besides, the Kering Group sets up a pioneering device, the Environmental Profit\&Loss (E P\&L), which allows to make visible, quantifiable and comparable the invisible impact of business on environment; this tool helps to develop a knowledgeable decision-making processes, which take into account the environmental footprint along the entire value chain. All the initiatives launched in latest years under the banner of sustainability, as well as the individual 
actions undertaken by the Group's brands are part of a sustainability holistic strategy that allowed Kering to rapidly increase and consolidate its reputation (and the reputation of the brands in its portfolio) among luxury consumers, suppliers, investors, creative directors, artists and other relevant stakeholders. Today the innovative business model of the Kering Group is a globally recognized as a benchmark to which a growing number of players in the luxury watch, with growing interest in order to both address the challenge of sustainable growth and seize the opportunities offered by the new competitive scenario. These important steps towards a truly sustainable business model based on innovation and on the control of the entire value chain are made possible by the existence of a leadership that is receptive to social and environmental problems, a factor that unites all the most innovative experiments now emerging in the luxury fashion industry (Table 2).

Table 2. The luxury industry: critical success factors, drivers of innovations, CSR initiatives and their reputational impact

\begin{tabular}{|c|c|c|c|}
\hline $\begin{array}{l}\text { Critical success factors in } \\
\text { the luxury industry }\end{array}$ & $\begin{array}{l}\text { Main drivers } \\
\text { innovation }\end{array}$ & $\begin{array}{l}\text { CSR initiatives/actions } \\
\text { typical of the luxury } \\
\text { industry }\end{array}$ & $\begin{array}{l}\text { Main elements } \\
\text { impacting on corporate } \\
\text { reputation }\end{array}$ \\
\hline $\begin{array}{lrr}\text { Rarity, authenticity } & \text { and } \\
\text { timeless elegance } & \text { of } \\
\text { products and services } & \end{array}$ & $\begin{array}{l}\text { Science-driven } \\
\text { innovation guided by } \\
\text { technology }\end{array}$ & $\begin{array}{l}\text { Strict management of the } \\
\text { overall supply business } \\
\text { model }\end{array}$ & $\begin{array}{l}\text { Brand differentiation } \\
\text { based on good corporate } \\
\text { reputation }\end{array}$ \\
\hline $\begin{array}{l}\text { Exclusivity and positional } \\
\text { status of product offering }\end{array}$ & $\begin{array}{l}\text { Productive and artistic } \\
\text { innovation }\end{array}$ & $\begin{array}{l}\text { education, technical and } \\
\text { economic assistance to key } \\
\text { suppliers }\end{array}$ & $\begin{array}{l}\text { Growing pressure to } \\
\text { manage different cultural } \\
\text { contexts }\end{array}$ \\
\hline $\begin{array}{l}\text { Manufacturing } \\
\text { craftsmanship }\end{array}$ & & $\begin{array}{l}\text { Integration of the ecological } \\
\text { factors in the overall } \\
\text { company process }\end{array}$ & $\begin{array}{lr}\text { Customer } & \text { loyalty } \\
\text { connected } & \text { to } \\
\text { sustainability reputation }\end{array}$ \\
\hline $\begin{array}{l}\text { Ability to valorise the } \\
\text { "Made in" effect and the } \\
\text { cultural heritage }\end{array}$ & & $\begin{array}{l}\text { Endorsement of the value of } \\
\text { the work, the education of } \\
\text { the employees }\end{array}$ & \\
\hline $\begin{array}{l}\text { Traceability of the supply } \\
\text { chain }\end{array}$ & & $\begin{array}{l}\text { Support of the connections } \\
\text { with the local community }\end{array}$ & \\
\hline
\end{tabular}

\section{Methodology}

This study is focused on the role of CSR in the luxury industry and analyses how it helps to increase corporate reputation (Weiser \& Zadek, 2001). The methodology used is mainly qualitative.

At the base of the paper there is a theoretical framework which considers the existence of a positive relationship between CSR and reputation. CSR is analyzed under the three points of view (economic, ecological and social) and the research is conducted identifying the positive, neutral or negative relationship between CSR and reputation. In particular, with the use of case studies, the paper proposes an explanation of the effects of CSR on corporate reputation.

This paper makes use of a method based on two key topics. First, following Siltaoja (2006), the authors examined the connection between CSR and reputation by conducting a literature review and subsequently explained the idea of merging trends of luxury brands about the reputation and the future trend to CSR reputation. Second, three companies that were considered the best practices for the Standard Ethics Italian Index are digitally analyzed. In the research, the case study methodology resulting from the social sciences (Eisenhardt, 1989; Yin, 2013) and applied also in other fields research is used (Gazzola \& Pavione, 2019). The "case study" methodology allows understanding a problem or simplifying a complex object; it can also reinforce the conclusions of previous research.

In the paper the luxury Italian companies included in the Standard Ethics Italian Index (2015) are analyzed. It measures the quality of the governance model. Standard Ethics is a "benchmark to measure, over time, the appreciation in financial markets of the principles and guidelines from the European Union, the OECD and the United Nations on sustainability, corporate governance and corporate social responsibility issues" (http://www.standardethicsindices.eu/indices.html). Standard Ethics represents, since 2013, the first autonomous 
European Sustainability rating agency which publishes the annual ranking of the forty largest listed companies on the basis of Standard Ethics Rating (ERA). The six-monthly review of the Italian Standard Ethics Index will be based on this ranking.

There are three different indexes:

- The Standard Ethics index

- The Standard Ethics Mid Italian Index: the constituents are 12 Italian listed companies with market capitalization above 250 million EUR

- The Standard Ethics Small Italian Index: the constituents are 12 Italian listed companies with market capitalization below 250 million EUR.

We choose the three Italian luxury companies that in 2015 represented best practices by Standard Ethics Italian Index and we analyzed the evolutionary profile: Luxottica for Standard Ethics index, Brunello Cucinelli for the Standard Ethics Mid and Damiani for Standard Ethics Small.

\section{CSR and Sustainability in Italia Luxury Sector: a Digital Analysis of Three Virtuous Family Firms Case- Studies}

The overall Italian luxury industry is still very weak in terms of models of corporate governance and management of reputational risks, which are warned, mostly, in terms of product quality.

With this idea, Italian luxury companies forget other aspects that affect the reputation and that are increasingly felt by stakeholders. For example, in 2014 an Italian TV programmes reported the bad practices of a leading Italian jacket makers Moncler to mistreat animals, accused of cruel actions against geese (Report, 2014) and resulting in a 6\% fall in shares. The Moncler scandal is just one of several examples.

The Italian market also shows positive examples. The Italian Standard Ethics Index offers an important harmonized rating classification: the Standard Ethics Rating (SER). The Italian companies belonging to the Italian Standard Ethics Index, are: Ferragamo, Moncler, Tod's and Luxottica (Figure 1). The paper presents the analysis of three family firms Luxottica, Brunello Cucinelli for the Standard Ethics Mid (Figure 2) and Damiani for Standard Ethics Small (Figure 3) (Tab. 3).

Since 2015, the situation of the three companies analyzed has changed, as they are no longer part of the index. In order to take into account this fact, the paper analyses how it may have had repercussions on corporate profit and how the concept of CSR has evolved within these family firms.

\begin{tabular}{|c|c|}
\hline Company & Wolghts \\
\hline ENI & $725 x$ \\
\hline ENEL & $598 x$ \\
\hline UNICREDIT & 5.985 \\
\hline PRYSMMLN & $486 x$ \\
\hline AZMUT & 4.496 \\
\hline ENCL GREEN POWER & 4.096 \\
\hline GENERALI & 4.95 \\
\hline ST UICROELECTR & $4.99 \mathrm{x}$ \\
\hline VBI BANCA & $4.0 \%$ \\
\hline EANCA POP, EMILA ROM. & $4.11 \mathrm{x}$ \\
\hline BANCO POPOURE & $411 x$ \\
\hline SAIPEM & $4.11 \mathrm{x}$ \\
\hline FNMECCCANICA & $13 n$ \\
\hline NTESA SAN PAOLO & $3.37 x$ \\
\hline ANIMA HOLOING & $2 m$ \\
\hline$A 2 A$ & $2 m$ \\
\hline BUNCA POP, MLANO & 29.96 \\
\hline Luxotrica & $29 \mathrm{~m}$ \\
\hline SNAMRETE GAS & $2 m$ \\
\hline TELECOM ITALAA & $2 m$ \\
\hline
\end{tabular}

\begin{tabular}{|c|c|}
\hline Cempany & Woights \\
\hline YOOX NET-APORTER & 2.995 \\
\hline CAMPARI & $262 \mathrm{~S}$ \\
\hline MEDIOBANCA & $1.50 \mathrm{~K}$ \\
\hline UNIPOLSN & 1 sos \\
\hline ANSALDOSTS & 1126 \\
\hline BANCAMPS & $212 \mathrm{~K}$ \\
\hline TENARIS & 1125 \\
\hline Too's & $1.12 \mathrm{~K}$ \\
\hline ITNLCEMENTI & $112 \mathrm{~K}$ \\
\hline BUZZI UNICEM & $0.37 \mathrm{x}$ \\
\hline ATUNTIA & 0.195 \\
\hline AUTOCRIL & $0.19 \%$ \\
\hline CNH INDUSTRLLL & $0.19 x$ \\
\hline EXOR & 0.95 \\
\hline $\mathrm{FCA}$ & 0.195 \\
\hline MONUCLER & $0.19 \%$ \\
\hline SMLVATORE FERRAGMIO & $0.19 x$ \\
\hline TERNA & $0.19 \%$ \\
\hline MEDUSET & 0.075 \\
\hline MEDIOLNUIA & $0.07 \mathrm{x}$ \\
\hline
\end{tabular}

Figure 1. The Italian standard ethics index: constituents and weights

Source: http://standardethicsrating.eu (30th October 2015) 


\subsection{Luxottica: CSR and Reputation}

The company is today among the most important Italian family firm acting in the global luxury market and shows an evident orientation towards social responsibility (Colombo \& Gazzola, 2014). This orientation is embedded in the company's: "to making the best eyewear in the world - innovative in design and excellent in quality - to enable people to see and enjoy the beauty of life in all its forms" (http://www.luxottica.com/en/sustainability/see-beautylife).

Central elements of Luxottica's responsible approach are the respect for people and the environment, the "involvement" and the "sense of identification" of the employees to the company's objectives, in the belief that such elements strongly contribute to increase the company's competitiveness (Salomoni, 2011). Luxottica has adopted both a "Code of Conduct" and a "Code of Ethics" intended for workers, commercial collaborators and suppliers. The Codes prescribe ethical and legal behavior (up to and including the Universal Declaration of Human Rights) for all those who interact in a professional capacity for Luxottica. The company also provides for the protection of workers' rights and promotes freedom of association and conducts a deep analysis of its suppliers before initiating supply relationships, by exercising a continuous control over them during the time. Luxottica's next goal is to adopt a global audit program on CSR issues. (www.luxottica.com).

Luxottica is the first Luxury Company in the Italian Standard Ethics Index for its CSR (Figure 1). The company has a strong and long-lasting good reputation. In 2014, Luxottica was on the third place for reputation among Italian companies according to the ranking provided by the Reputation Institute - Italy Rep Trak®. In 2015 Luxottica was eighth in the ranking (Reputation Institute 2015). In 2016, Luxottica started to communicate its approach to sustainability by publishing a non-financial annual Report. Although this company is no longer part of the Index, it has continued to undertake socially responsible initiatives. The profit has increased over the years, reaching 900 million in 2018. In 2019 Standard Ethics gave to the group Essilor Luxottica the "EE-" rating. The company is part of the Standard Ethics French Index, the result is connected to the sustainability strategy and the non-financial report.

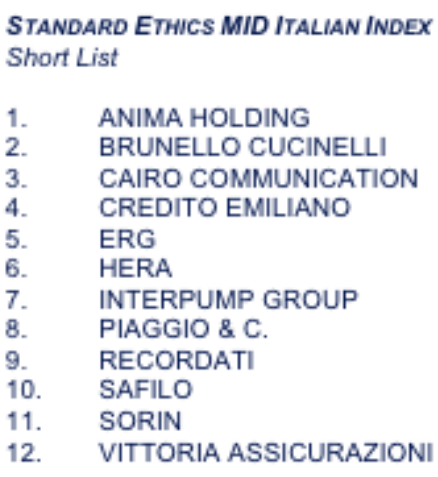

Figure 2. The standard ethics mid Italian index

Source: http:// standardethicsrating.eu (1st July 2015)

\subsection{Brunello Cucinelli: A Humanistic Approach to Luxury}

Brunello Cucinelli $\mathrm{SpA}$ is an Italian internationally recognized family firm which occupies the first positions in the pyramid of luxury for the production of Made in Italy cashmere clothing. The company is considered an example of "absolute luxury", combining Italian manufacturing quality with innovative capacity (Gazzola, 2014a). An essential feature is the centrality of people in the production process, in which the employee (but also the collaborator) feels an active part of the company's success and of the achievement of the group's objectives (LaRocca, 2014). The company has a business model in line with consumers' demand which leads it to be defined as a "humanistic enterprise". In fact, luxury consumers "want to know, or will want to know, that their goods are humanly manufactured" (Croce, 2013). In particular, one third of profits go to employees, while the remaining two thirds are distributed between the community and entrepreneur. The company has managed to grow over the years, even during the crisis, both in terms of earnings and reputation (Corbellini \& Marafioti, 2013). Cucinelli intends to "giving 
companies a meaning that goes beyond profit and reinvesting to improve workers' lives, improve and restore the beauty of the world" in an excellent "supreme good" for workers and the environment. Cucinelli is a company in which CSR orientation has been part of the company's genetic heritage since the beginning due to the existence of a top management highly sensitive to social responsibilities topics.

Starting from 2017, the company began to have a strong focus on CSR when it published the first "non-financial disclosure" report. In addition, the company has dedicated a "Harmony and sustainability" section on the web page. Brunello Cucinelli is the first luxury company in the Italian Standard Ethics Mid index for its CSR (Figure 2).

Even this company is no longer part of the index considered but nevertheless, like Luxottica, it has continued to adopt a strong socially responsible approach to business. Also in this case the profit passed from 31.8 million in 2014 to 52 million in 2018. According to the Reputation Science Observatory for web reputation, in 2019 Brunello Cucinelli was the best Italian manager in the luxury sector.

\begin{tabular}{|c|c|}
\hline \multicolumn{2}{|c|}{$\begin{array}{l}\text { STANDARD ETHICS SMALL ITALIAN INDEX } \\
\text { Short List }\end{array}$} \\
\hline 1. & B\&C SPEAKERS \\
\hline 2. & BANCO DESIO BRIANZA \\
\hline 3. & BEGHELLI \\
\hline 4. & DAMIANI \\
\hline 5. & FIERA MILANO \\
\hline 6. & JUVENTUS F.C. \\
\hline 7. & MITTEL \\
\hline 8. & PININFARINA \\
\hline 9. & RENO DE MEDICI \\
\hline 10. & SABAF \\
\hline 11. & TISCALI \\
\hline 12. & ZUCCHI \\
\hline
\end{tabular}

Figure 3. The standard ethics small Italian index

Source: http://standardethicsrating.eu (1st July 2015)

\subsection{Damiani}

Damiani S.p.A is an Italian family company operating in the luxury jewelry and watches sector based of the following ideals: respect, for work, the market and people (www.damianigroup.com). The company gives great importance to the supply chain and also carefully selects suppliers on the basis of compliance with UN regulations on diamonds. The company follows the Kimberley Process, in order to remove the "diamond problem", rough diamonds that become tools to finance conflicts against legitimate governments. Damiani is the first Luxury companies in the Italian Standard Ethics Small Index for its CSR (Figure 3). The company doesn't release the annual Sustainability Report, but in the web page of the Damiani Group is present the Sustainability section showing also the company project for Ethical diamonds.

Unlike the other two case studies, Damiani once has left the Index, no longer continued to take socially responsible initiatives: it has not implemented a specific Sustainability and CSR function internally. Damiani, unlike Luxottica and Brunello Cucinelli, is not part of the "Map of sustainability". The Sustainability Map is the first photograph of responsible companies in Italy. The initiative, conceived by the CSR natives network (a network of university and recent graduates whose goal is to network those who are building sustainability skills, support those who want to become a CSR manager, promote the culture of sustainability, enhance the experiences of social innovation) and coordinated by Koinètica (the first reality in Italy exclusively dedicated to corporate social responsibility), intends to enhance the companies of every sector and dimension that have started a path of sustainability in the different Italian regions.

From 2014 to 2018 Damiani went from a profit (6.5 million) to a loss (3.9 million). However, from June 2018 Damiani joined the "Mani Intelligenti" Foundation. Behind this Foundation there is indirectly an important CSR project that is combined with the true respect and enhancement of all the stakeholders involved (including the Municipality of Valenza); this becomes a mix of elements that directly or indirectly can have important repercussions in terms of social and economic impact. 
Table 3. Synthesis of the three case studies

\begin{tabular}{|c|c|c|c|}
\hline Company & Luxottica & Brunello Cucinelli & Damiani \\
\hline Index & Standard Ethics Index & Standard Ethics Mid & Standard Ethics Small \\
\hline Dimension & large & medium & small \\
\hline Revenues 2014/2015 & $€ 7,698$ billion & $€ 355,9$ million & $€ 121$ million (9 month) \\
\hline Profit 2014 & $€ 642$ million & $€ 31,8$ million & $€ 6,5$ million (9 month) \\
\hline CSR view & philanthropic programs & $\begin{array}{l}\text { the socially responsible } \\
\text { vision is intrinsic to the } \\
\text { company's way of being }\end{array}$ & social commitment \\
\hline Respect of environment & $\begin{array}{l}\text { believe in environmental } \\
\text { sustainability }\end{array}$ & yes & no information \\
\hline Respect for people & $\begin{array}{l}\text { Code of Conduct, ethics } \\
\text { code }\end{array}$ & $\begin{array}{l}\text { person is the central element } \\
\text { of the production process }\end{array}$ & $\begin{array}{l}\text { respect and promotion of } \\
\text { ethics (of work, of the } \\
\text { market, of people) } \\
\text { represent basic values }\end{array}$ \\
\hline Reputation & $\begin{array}{l}\text { third place for reputation } \\
\text { in 2014, among Italian } \\
\text { companies }\end{array}$ & $\begin{array}{l}\text { award "Cresci Italia" for } \\
\text { reputation and credibility }\end{array}$ & $\begin{array}{l}\text { quality of product and } \\
\text { important client }\end{array}$ \\
\hline Sustainability report & no & no & no \\
\hline Revenues 2017/2018 & $€ 8,929$ billion & $€ 553$ milion & $€ 164$ million \\
\hline Profit 2018 & $€ 900$ milion & $€ 52$ million & $€(3,9$ million $)$ \\
\hline Sustainability report & yes & yes & no \\
\hline
\end{tabular}

\section{Conclusions}

For the luxury industry, social responsibility is becoming a concept of greater importance. The strategic vision of companies gives increasing attention to concepts such as ethics, environmental and social impact. Luxury consumers' improved attention to sustainability, the need to assure the supply (and the control) of scarce and valuable raw materials faced to risks due to climate change, along with the need to assure the prosperity in the long-term of their brands, causes luxury firms to adopt a proactive engagement in sustainability practices as a central part of their business strategy. By giving visibility at the supply chain of their products, luxury companies are able to reveal to consumers and other stakeholders their values and vision; this allows to differentiate their brands and to increase the reputation by integrating CSR in their business model. In the current competitive environment, reputation is becoming luxury companies' greatest intangible asset and, increasingly, it acts as a source of powerful long-lasting competitive advantage. Pioneering empirical analysis on top companies in the luxury industry confirm that the companies' attitude towards CSR is rapidly changing: from being seeing as a mere marketing tool (often adopted, in a reactive way, for green washing goals) sustainability is more and more becoming an essential part of the strategic vision and impacts on the business model, together with a thrust factor of powerful brand differentiation. In many luxury sectors, sustainability is also revealing a powerful driver of innovation, which involves not only the product side, but also the managerial philosophy and the business models. These trends, today in a phase of growing affirmation, are contributing to redefining and updating the meaning of luxury, strictly linked to the values of sustainability and social responsibility increasingly demanded by both customers and the society. This perspective open today new luxury segments in many sectors (such as food, cosmetics, textile, eyewear,...) and support the rapid affirmation of new eco-luxury brands which are basing their value proposition on the 3Rs model: re-use, recycle, reduce. According to Altagamma Foundation, eco-luxury goods today account for $3 \%$ of total sales volumes of personal luxury goods, a trend showing a rapid expansion globally. The three case studies analyzed in the paper confirm the trends towards sustainable luxury, especially in family firms where CSR proves to be more effective (Gavana, Gottardo, \& Moisello, 2018). Luxury companies are pursuing sustainable practices and organizing a variety of social and ecological activities, but still numerous companies don't communicate their social and environmental initiatives and they do not publish non-financial sustainability report. The paper also shows that luxury companies 
like Luxottica and Brunello Cucinelli, which strongly invested in CSR practices during the time have highlighted an increase in profit. Damiani, on the other hand, opting for the non-adoption of CSR behaviors, has suffered a reduction in the economic result, going from a solid profit to a considerable loss.

\section{References}

Adams, C. A. (2002). Internal organisational factors influencing corporate social and ethical reporting: Beyond current theorising. Accounting, Auditing \& Accountability Journal, 15(2), 223-250. https://doi.org/10.1108/09513570210418905

Advantage, C. (2020). Corporate Social Responsibility. CSR and Socially Responsible Investing Strategies in Transitioning and Emerging Economies, 65.

Aggarwal, P., \& Singh, A. K. (2019). CSR and sustainability reporting practices in India: an in-depth content analysis of top-listed companies. Social Responsibility Journal, 15(8), 1033-1053. https://doi.org/10.1108/SRJ03-2018-0078

Allen, M. W., Walker, K. L., \& Brady, R. (2012). Sustainability discourse within a supply chain relationship: Mapping convergence and divergence. The Journal of Business Communication (1973), 49(3), 210-236. https://doi.org/10.1177/0021943612446732

Alonso-Dos-Santos, M., \& Llanos-Contreras, O. (2019). Family business performance in a post-disaster scenario: The influence of socioemotional wealth importance and entrepreneurial orientation. Journal of Business Research, 101, 492-498. https://doi.org/10.1016/j.jbusres.2018.12.057

Andriof, J. A. (2002). Unfolding Stakeholder Engagement. In J. Andriof, S. Waddock, B. Husted, \& S. Sutherland Rahman (Eds.), Unfolding stakeholder thinking: theory, responsibility and engagement.

Aronoff, C. E., \& Ward, J. L. (1991). Family business sourcebook. Omnigraphics.

Astrachan, C. B., Botero, I., Astrachan, J. H., \& Prügl, R. (2018). Branding the family firm: A review, integrative framework proposal, and research agenda. Journal of Family Business Strategy, 9(1), 3-15. https://doi.org/10.1016/j.jfbs.2018.01.002

Barnett, J. E., Johnston, L. C., \& Hillard, D. (2006). Psychotherapist wellness as an ethical imperative. Innovations in Clinical Practice: Focus on Health and Wellness, 257-271.

Bartel, C. A., Blader, S., \& Wrzesniewski, A. (2007). Identity and the modern organization. Mahwah, NJ: Lawrence Erlbaum.

Bartikowski, B., Fastoso, F., \& Gierl, H. (2020). How nationalistic appeals affect foreign luxury brand reputation: A study of ambivalent effects. Journal of Business Ethics, 1-17.

Basco, R., \& Calabrò, A. (2017). "Whom do I want to be the next CEO?" Desirable successor attributes in family firms. Journal of Business Economics, 87(4), 487-509. https://doi.org/10.1007/s11573-016-0828-2

Beheshtifar, M., \& Korouki, A. (2013). Reputation: an important component of corporations' value. International Journal of Academic Research in Business and Social Sciences, 3(7), 15.

Berland, N., \& Essid, M. (2009). RSE, systèmes de contrôle et pilotage de la performance globale. Proceeding of 28th AFC (French Management Accounting) Annual Congrees (Poitiers, France)-27-29 May 2009.

Berrone, P., Cruz, C., \& Gomez-Mejia, L. R. (2012). Socioemotional wealth in family firms: Theoretical dimensions, assessment approaches, and agenda for future research. Family Business Review, 25(3), 258-279. https://doi.org/10.1177/0894486511435355

Beverland, M. (2006). The 'real thing': Branding authenticity in the luxury wine trade. Journal of Business Research, 59(2), 251-258. https://doi.org/10.1016/j.jbusres.2005.04.007

Bianchi, E., Bruno, J. M., \& Sarabia-Sanchez, F. J. (2019). The impact of perceived CSR on corporate reputation and purchase intention. European Journal of Management and Business Economics, 28(3), 206-221. https://doi.org/10.1108/EJMBE-12-2017-0068

Block, J. H., \& Wagner, M. (2014). The effect of family ownership on different dimensions of corporate social responsibility: Evidence from large US firms. Business Strategy and the Environment, 23(7), 475-492. https://doi.org/10.1002/bse.1798

Bouchikhi, H., \& Kimberly, J. R. (2008). The soul of the corporation: How to manage the identity of your company. 
Upper Saddle, NJ: Wharton School Publishing.

Brammer, S. J., \& Pavelin, S. (2006). Corporate reputation and social performance: The importance of fit. Journal of Management Studies, 43(3), 435-455. https://doi.org/10.1111/j.1467-6486.2006.00597.x

Bussoli, C., \& Conte, D. (2018). The "Virtuous Circle" Between Corporate Social Performance and Corporate Financial Performance in the European Banking Sector. International Journal of Business Administration, 9(2), 80-92. https://doi.org/10.5430/ijba.v9n2p80

Carcano, L., Corvetta, G., \& Minichilli, A. (2011). Why luxury firms are often family firms? Family identity, symbolic capital and value creation in luxury-related industries. Universia Business Review, (32), 40-53.

Catry, B. (2003). The great pretenders: the magic of luxury goods. Business Strategy Review, 14(3), 10-17. https://doi.org/10.1111/1467-8616.00267

Chatterji, A. K., Levine, D. I., \& Toffel, M. W. (2009). How well do social ratings actually measure corporate social responsibility?. Journal of Economics \& Management Strategy, 18(1), 125-169. https://doi.org/10.1111/j.15309134.2009.00210.x

Claver-Cortés, E., Marco-Lajara, B., Úbeda-García, M., García-Lillo, F., Rienda-García, L., Zaragoza-Sáez, P. C., ... Sánchez-García, E. (2020). Students' perception of CSR and its influence on business performance. A multiple mediation analysis. Business Ethics: A European Review. https://doi.org/10.1111/beer.12286

Colombo, G., \& Gazzola, P. (2014). Aesthetics and ethics of the sustainable organizations. European Scientific Journal, 2, 291-301.

Colombo, G., \& Gazzola, P. (2015a). Building CSR in the corporate strategy, Strategica. International Academic Conference (3rd ed.). Bucharest, Romania.

Colombo, G., \& Gazzola, P. (2015b). From Uncertainty to Opportunity: How CSR Develops Dynamics Capabilities. EURAM 2015-15th Annual Conference of European Academy of Management, Warsaw, 17-20 June 2015.

Corbellini, E., \& Marafioti, E. (2013). La CSR nella moda. Strumento di marketing o elemento fondante della strategia d'impresa?. Economia \& Management, 3, 61-80.

Cross, H. (2013). Artisanship, CSR and the End of "High End" Fashion. Culture-ist June 19. Retrieved May 10, 2019, from http://www.thecultureist.com

Cruz, C., Larraza-Kintana, M., Garcés-Galdeano, L., \& Berrone, P. (2014). Are family firms really more socially responsible?. Entrepreneurship Theory and Practice, 38(6), 1295-1316. https://doi.org/10.1111/etap.12125

De Castro, G. M., López, J. E. N., \& Sáez, P. L. (2006). Business and social reputation: Exploring the concept and main dimensions of corporate reputation. Journal of Business Ethics, 63(4), 361-370. https://doi.org/10.1007/s10551-005-3244-z

De Leaniz, P. M. G., \& Ruiz, M. E. G. (2019). Integrating Sustainability and CSR in the Value Chain of the Information Technology Sector. In Advanced methodologies and technologies in government and society (pp. 38-49). IGI Global.

Deephouse, D. L. (2000). Media reputation as a strategic resource: An integration of mass communication and resource-based theories. Journal of Management, 26(6), 1091-1112. https://doi.org/10.1177/014920630002600602

Dekhili, S., Achabou, M. A., \& Alharbi, F. (2019). Could sustainability improve the promotion of luxury products?. European Business Review, 31(4), 488-511. https://doi.org/10.1108/EBR-04-2018-0083

Donato, C., Amatulli, C., \& De Angelis, M. (2019). Responsible Luxury Development: A Study on Luxury Companies' CSR, Circular Economy, and Entrepreneurship. In Sustainable luxury (pp. 21-38). Springer, Singapore.

Donnelley, R. G. (1964). The family business. Harvard Business Review, 42(4), 93-105.

Dyer Jr, W. G., \& Whetten, D. A. (2006). Family firms and social responsibility: Preliminary evidence from the S\&P 500. Entrepreneurship Theory and Practice, 30(6), 785-802. https://doi.org/10.1111/j.1540-6520.2006.00151.x

Eisenhardt, K. M. (1989). Building theories from case study research. Academy of Management Review, 14(4), 532550. https://doi.org/10.5465/amr.1989.4308385

Fernández-Gago, R., Cabeza-García, L., \& Nieto, M. (2016). Corporate social responsibility, board of directors, and 
firm performance: an analysis of their relationships. Review of Managerial Science, 10(1), 85-104. https://doi.org/10.1007/s11846-014-0141-9

Fombrun, C. J. (1996). Reputation. Massachusetts: Harvard Business School Press.

Fombrun, C. J. (2005). A world of reputation research, analysis and thinking — building corporate reputation through CSR initiatives: evolving standards. Corporate Reputation Review, 8(1), 7-12. https://doi.org/10.1057/palgrave.crr.1540235

Fombrun, C. J., \& Van Riel, C. B. M. (1997). The reputational landscape. Corporate Reputation Review, 1(1/2), 5-13.

Fondazione Altagamma. (2012). Worldwide market monitor. Milano: Fondazione Altagamma.

Freeman, I., \& Hasnaoui, A. (2011). The meaning of corporate social responsibility: The vision of four nations. Journal of Business Ethics, 100(3), 419-443. https://doi.org/10.1007/s10551-010-0688-6

Friedman, M. (2007). The social responsibility of business is to increase its profits. In Corporate ethics and corporate governance (pp. 173-178). Springer, Berlin, Heidelberg. https://doi.org/10.1007/978-3-540-70818$6 \_14$

Galbreath, J. (2009). Building corporate social responsibility into strategy. European Business Review, 21(2), 109127. https://doi.org/10.1108/09555340910940123

Gavana, G., Gottardo, P., \& Moisello, A. (2018). Do Customers Value CSR Disclosure? Evidence from Italian Family and Non-Family Firms. Sustainability, 10(5), 1642. https://doi.org/10.3390/su10051642

Gazzola, P. (2014a). CSR: focus on employees. Italian cases. Annals of the University of Oradea, Economic Science Series, 23(2), 11-21.

Gazzola, P. (2014b). Corporate social responsibility and companies' reputation. Network Intelligence Studies, 2(03), 74-84.

Gazzola, P. (2018). Ethical Behaviour Integrated in CSR: How to create and maintain the Corporate Reputation. Economia Aziendale Online, 9(2), 175-185.

Gazzola, P., \& Colombo, G. (2014). CSR integration into the corporate strategy. Cross-Cultural Management Journal, 16(2).

Gazzola, P., \& Pavione, E. (2019). Sustainable Development and Social Market Economy to Promote a Culture of Peace. In Marketing peace for social transformation and global prosperity (pp. 143-178). IGI Global.

Gazzola, P., Amelio, S., Papagiannis, F., \& Michaelides, Z. (2019). Sustainability reporting practices and their social impact to NGO funding in Italy. Critical Perspectives on Accounting. https://doi.org/10.1016/j.cpa.2019.04.006

Gazzola, P., Pavione, E., \& Pezzetti, R. (2017, February). Sustainable consumption in the luxury industry: Towards a new paradigm in China's high-end demand. In Proceedings of the 2nd Czech-China Scientific Conference 2016. IntechOpen.

Gazzola, P., Pezzetti, R., Amelio, S., \& Grechi, D. (2020). Non-Financial Information Disclosure in Italian Public Interest Companies: A Sustainability Reporting Perspective. Sustainability, 12, 60-63. https://doi.org/10.3390/su12156063

Girón, M. E. (2010). Inside Luxury. London: LID Publishing Ltd.

Gnan, L., \& Montemerlo, D. (2002). The multiple facets of family firms' social role: Empirical Evidence from Italian SMEs.

Graf, C., \& Wirl, F. (2014). Corporate social responsibility: a strategic and profitable response to entry?. Journal of Business Economics, 84(7), 917-927. https://doi.org/10.1007/s11573-014-0739-z

Gray, E. R., \& Balmer, J. M. (1998). Managing corporate image and corporate reputation. Long Range Planning, 31(5), 695-702. https://doi.org/10.1016/S0024-6301(98)00074-0

Guercini, S., \& Ranfagni, S. (2012, June). Social and green sustainability and the Italian Mediterranean fashion brands. In EUROMED congress marseille (pp. 28-29).

Hoffmann, J., \& Coste-Maniere, I. (2012). Luxury strategy in action. New York: Palgrave Macmillan.

Holbrook, M. B. (1999). Consumer value: a framework for analysis and research. Psychology Press. 
Jaegler, A., \& Goessling, T. (2020). Sustainability concerns in luxury supply chains: European brand strategies and French consumer expectations. Business Strategy and the Environment, 29(6), 2715-2733. https://doi.org/10.1002/bse.2531

Janssen, C., Vanhamme, J., Lindgreen, A., \& Lefebvre, C. (2014). The Catch-22 of responsible luxury: Effects of luxury product characteristics on consumers' perception of fit with corporate social responsibility. Journal of Business Ethics, 119(1), 45-57.

Jarzabkowski, P. (2005). Strategy as practice: An activity based approach. London: Sage.

Kapferer, J. N. (1997). Managing luxury brands. Journal of Brand Management, 4(4), 251-260.

Kashmiri, S., \& Mahajan, V. (2014). A rose by any other name: Are family firms named after their founding families rewarded more for their new product introductions?. Journal of Business Ethics, 124(1), 81-99. https://doi.org/10.1007/s10551-013-1861-5

Kelley, K. J., Hemphill, T. A., \& Thams, Y. (2019). Corporate social responsibility, country reputation and corporate reputation. Multinational Business Review, 27(2), 178-197. https://doi.org/10.1108/MBR-07-2017-0047

Kiesnere, A. L., \& Baumgartner, R. J. (2019). Sustainability management emergence and integration on different management levels in smaller large-sized companies in Austria. Corporate Social Responsibility and Environmental Management, 26(6), 1607-1626. https://doi.org/10.1002/csr.1854

Kucharska, W. (2020). Employee commitment matters for CSR practice, reputation and corporate brand performance-European model. Sustainability, 12(3), 940. https://doi.org/10.3390/su12030940

LaRocca, D. (2014). Brunello Cucinelli: A humanistic approach to luxury, philanthropy, and stewardship. Journal of Religion and Business Ethics, 3(1), 9.

Lee, Y. G., \& Marshall, M. I. (2013). Goal orientation and performance of family businesses. Journal of Family and Economic Issues, 34(3), 265-274. https://doi.org/10.1007/s10834-012-9329-9

Marques, P., Presas, P., \& Simon, A. (2014). The heterogeneity of family firms in CSR engagement: The role of values. Family Business Review, 27(3), 206-227. https://doi.org/10.1177/0894486514539004

McKinsey. (2009). Valuing corporate social responsibility. McKinsey Global Survey Results.

McKinsey. (2010). How Companies Manage Sustainability. Mckinsey Global Survey Results. Retrieved February 8, 2019, from https://www.mckinsey.com/

Mella, P., \& Gazzola, P. (2015). Reputation in the creation of value for the stakeholders. Annals of the University of Oradea, Economic Science Series 24.

Mella, P., \& Gazzola, P. (2018). Corporate social responsibility through stakeholder engagement and entrepreneurial communication processes. International Journal of Business Performance Management, 19(1), 36-54. https://doi.org/10.1504/IJBPM.2018.088495

Mirvis, P., \& Googins, B. (2006). Stages of corporate citizenship. California Management Review, 48(2), 104-126.

Mollet, J. C., Von Arx, U., \& Ilić, D. (2013). Strategic sustainability and financial performance: exploring abnormal returns. Journal of Business Economics, 83(6), 577-604. https://doi.org/10.1007/s11573-013-0664-6

Norris, G., \& O'Dwyer, B. (2004). Motivating socially responsive decision making: the operation of management controls in a socially responsive organisation. The British Accounting Review, 36(2), 173-196. https://doi.org/10.1016/j.bar.2003.11.004

Othman, S., Darus, F., \& Arshad, R. (2011). The influence of coercive isomorphism on corporate social responsibility reporting and reputation. Social Responsibility Journal, 7(1), 119-135. https://doi.org/10.1108/17471111111114585

Park, E. (2019). Corporate social responsibility as a determinant of corporate reputation in the airline industry. Journal of Retailing and Consumer Services, 47, 215-221.

Pavione, E., \& Pezzetti, R. (2015). Responsible and sustainable luxury in the global market: new emerging strategies in the luxury sector. In Strategica (Ed.), International Academic Conference: Local Versus Global (pp. 73-80).

Pavione, E., Pezzetti, R., \& Dall'Ava, M. (2016). Emerging competitive strategies in the global luxury industry in the perspective of sustainable development: The case of Kering Group. Management Dynamics in the Knowledge Economy, 4(2), 241-261. 
Pencarelli, T., Ali Taha, V., Škerháková, V., Valentiny, T., \& Fedorko, R. (2020). Luxury Products and Sustainability Issues from the Perspective of Young Italian Consumers. Sustainability, 12(1), 245. https://doi.org/10.3390/su12010245

Pini, M. (2019). Corporate social responsibility, family firms and territorial institutions in Italy: an empirical analysis. RIEDS-Rivista Italiana di Economia, Demografia e Statistica-Italian Review of Economics, Demography and Statistics, 73(2), 99-110.

Porter, M. E., \& Kramer, M. R. (2002). The competitive advantage of corporate philanthropy. Harvard Business Review, 80(12), 56-68.

Porter, M. E., \& Kramer, M. R. (2006). The link between competitive advantage and corporate social responsibility. Harvard Business Review, 84(12), 78-92.

Rendtorff, J. D. (2019). Corporate Social Responsibility, Sustainability, and Stakeholder Management (pp. 43-52). Philosophy of Management and Sustainability: Rethinking Business Ethics and Social Responsibility in Sustainable Development. https://doi.org/10.1108/978-1-78973-453-920191004

Report. (2014). Siamo tutti oche. Retrieved from www.report.rai.it

Reputation Institute. (2014). Most reputable companies in Italy in 2014. Retrieved February 15, 2019, from http://www.reputationinstitute.com

Reputation institute. (2015). Most reputable companies in Italy in 2015. Retrieved February 15, 2019, from http://www.reputationinstitute.com

Reverte, C. (2016). Corporate social responsibility disclosure and market valuation: evidence from Spanish listed firms. Review of Managerial Science, 10(2), 411-435. https://doi.org/10.1007/s11846-014-0151-7

Rhee, M., \& Haunschild, P. R. (2006). The liability of good reputation: A study of product recalls in the US automobile industry. Organization Science, 17(1), 101-117. https://doi.org/10.1287/orsc.1050.0175

Roberts, S. (2003). Supply chain specific? Understanding the patchy success of ethical sourcing initiatives. Journal of Business Ethics, 44(2-3), 159-170. https://doi.org/10.1023/A:1023395631811

Sabri, T., \& Sweis, K. (2016). Effect of corporate social responsibility on profitability of banks working in Palestine (case study 2013-2014). International Journal of Business Administration, 6(7), 107-114. https://doi.org/10.5430/ijba.v7n6p107

Sageder, M., Mitter, C., \& Feldbauer-Durstmüller, B. (2018). Image and reputation of family firms: a systematic literature review of the state of research. Review of Managerial Science, 12(1), 335-377. https://doi.org/10.1007/s11846-016-0216-x

Salomoni, C. (2011). Qualità e Walfare. Il caso Luxottica. Milano: Guerini Associati.

Santos, M. (2011). CSR in SMEs: strategies, practices, motivations and obstacles. Social Responsibility Journal, 7(3), 490-508. https://doi.org/10.1108/17471111111154581

Schnietz, K. E., \& Epstein, M. J. (2005). Exploring the financial value of a reputation for corporate social responsibility during a crisis. Corporate Reputation Review, 7(4), 327-345. https://doi.org/10.1057/palgrave.crr.1540230

Sciarelli, M., Tani, M., Landi, G., \& Turriziani, L. (2020). CSR perception and financial performance: Evidences from Italian and UK asset management companies. Corporate Social Responsibility and Environmental Management, 27(2), 841-851. https://doi.org/10.1002/csr.1848

Sharp, Z., \& Zaidman, N. (2010). Strategization of CSR. Journal of Business Ethics, 93(1), 51-71. https://doi.org/10.1007/s10551-009-0181-2

Siltaloppi, J., Rajala, R., \& Hietala, H. (2020). Integrating CSR with business strategy: A tension management perspective. Journal of Business Ethics, 1-21. https://doi.org/10.1007/s10551-020-04569-3

Siltaoja, M. E. (2006). Value priorities as combining core factors between CSR and reputation-a qualitative study. Journal of Business Ethics, 68(1), 91-111. https://doi.org/10.1007/s10551-006-9042-4

Silva Vilela, N. G., De Oliveira Santos Jhunior, R., \& Lemos Lourenço, M. (2020). Corporate Social Responsibility and Workers: Balancing Practices Analysis Between Work and Family. Capital Científico, 18(2).

Singh, S., \& Mittal, S. (2019). Analysis of drivers of CSR practices' implementation among family firms in India. 
International Journal of Organizational Analysis, 27(4), 947-971. https://doi.org/10.1108/IJOA-09-2018-1536

Standard Ethics Italian Index. (2015). Retrieved December 5, 2018, from http://standardethicsrating.eu

Szöcs, I., \& Schlegelmilch, B. B. (2020). Embedding CSR in Corporate Strategies. In Rethinking Business Responsibility in a Global Context (pp. 45-60). Springer, Cham.

Tetrault Sirsly, C. A., \& Lvina, E. (2019). From doing good to looking even better: The dynamics of CSR and reputation. Business \& Society, 58(6), 1234-1266. https://doi.org/10.1177/0007650315627996

Tynan, C., McKechnie, S., \& Chhuon, C. (2010). Co-creating value for luxury brands. Journal of Business Research, 63(11), 1156-1163. https://doi.org/10.1016/j.jbusres.2009.10.012

Vickers, J. S., \& Renand, F. (2003). The marketing of luxury goods: an exploratory study-three conceptual dimensions. The Marketing Review, 3(4), 459-478. https://doi.org/10.1362/146934703771910071

Vitezic, N. (2011). Corporate reputation and social responsibility: an analysis of large companies in Croatia. International Business \& Economics Research Journal (IBER), 10(8), 85-96. https://doi.org/10.19030/iber.v10i8.5380

Vitolla, F., \& Rubino, M. (2013). Strategic corporate social responsibility: a theoretical framework. African Journal of Business Management, 7(29), 2890-2904. https://doi.org/10.5897/AJBM2013.7003

Weiser, J., \& Zadek, S. (2001). Conversations with Disbelievers: Persuading Companies to Address Social Challenges. New York: Brody Weiser Burns and the Ford Foundation.

Yin, R. K. (2013). Case Study Research: Design and Methods (5th ed.). London: SAGE Pubblication.

Zanon, J., Scholl-Grissemann, U., Kallmuenzer, A., Kleinhansl, N., \& Peters, M. (2019). How promoting a family firm image affects customer perception in the age of social media. Journal of Family Business Strategy, 10(1), 28-37. https://doi.org/10.1016/j.jfbs.2019.01.007

Zeng, T. (2020). Corporate social responsibility (CSR) in Canadian family firms. Social Responsibility Journal. https://doi.org/10.1108/SRJ-12-2019-0410

Zody, Z., Sprenkle, D., MacDermid, S., \& Schrank, H. (2006). Boundaries and the functioning of family and business systems. Journal of Family and Economic Issues, 27(2), 185-206. https://doi.org/10.1007/s10834-0069017-8

Zyglidopoulos, S. C. (2001). The impact of accidents on firms' reputation for social performance. Business \& Society, 40(4), 416-441. https://doi.org/10.1177/000765030104000404

\section{Copyrights}

Copyright for this article is retained by the author(s), with first publication rights granted to the journal.

This is an open-access article distributed under the terms and conditions of the Creative Commons Attribution license (http://creativecommons.org/licenses/by/4.0/). 